\title{
Microbial thiamin metabolism in the rumen simulating fermenter (RUSITEC): the effect of acidogenic conditions, a high sulfur level and added thiamin
}

\author{
BY L. ALVES DE OLIVEIRA ${ }^{1}$, C. JEAN-BLAIN ${ }^{1}$, S. KOMISARCZUK-BONY ${ }^{1}$, \\ A. DURIX ${ }^{1}$ AND C. DURIER ${ }^{2}$ \\ 'Equipe associée INRA de Physiopathologie du rumen, Ecole Nationale Vétérinaire de Lyon, BP 83, \\ 69280 Marcy l'Etoile, France \\ ${ }^{2}$ Laboratoire de Biométrie INRA, Route de St Cyr - 78026 Versailles Cedex, France
}

(Received 27 August 1996 - Revised 28 April 1997 - Accepted 1 May 1997)

\begin{abstract}
The effects of acidogenic conditions, a high $S$ level and the addition of thiamin on the rumen microbial metabolism of thiamin were investigated in vitro in a semi-continuous fermenter (RUSITEC), using a factorial design. Acidogenic conditions were obtained by simultaneously increasing the starch : cellulose ratio and the amount of solid substrate fed, and by decreasing the buffering capacity of the liquid phase of the fermenter. $S$ in the form of sulfate was supplied at two levels, one corresponding to a control amount of $S(2 \mathrm{~g} / \mathrm{kg}$ dietary $D M)$, the second to an excess $(5 \mathrm{~g} /$ $\mathrm{kg}$ DM) which is sufficient to trigger cerebrocortical necrosis (CCN) when used in vivo. Acidogenic conditions decreased the $\mathrm{pH}$ of the fermenters, $\mathrm{CH}_{4}$ production and cellulose digestibility, increased the short-chain fatty acid production, but had no effect on thiamin production. The high $S$ level enhanced the production of sulfide considerably, had no effect on the microbial metabolism of energy and $N$, and decreased thiamin production $(326$ v. $266 \mathrm{nmol} / \mathrm{d})$. The added thiamin was rapidly converted into phosphorylated compounds which largely decreased the apparent synthesis of this vitamin by the rumen microflora. The total thiamin flow was increased by added thiamin. In no case was thiaminase activity in the fermenter liquid phase significantly modified. The high level of $S$ induced only a limited decrease of total thiamin flow. Consequently, it is unlikely that the investigated factors could be considered to be high risk factors for the thiamin-dependent $\mathrm{CCN}$.
\end{abstract}

Thiamin: Sulfur excess: Cerebrocortical necrosis

The independence of ruminants from dietary thiamin has been known for a considerable time (Bechdel et al. 1928). Under physiological conditions, the production of thiamin by the rumen microflora in the absence of an adequate dietary supply is much higher than the animal's requirements (Breves et al. 1981; Miller et al. 1986). However, the thiamin status can be altered and lead to cerebrocortical necrosis (CCN), a nervous syndrome well documented throughout the world. Previous studies (Edwin \& Jackman, 1973; Morgan \& Lawson, 1974; Shreeve \& Edwin, 1974; Boyd \& Walton, 1977; Boyd, 1985) have related this neurological disease to the development of high thiaminase activity in the rumen which destroys the vitamin and could induce a vitamin deficiency. However, little is known about micro-organisms which produce thiaminases in pathological conditions, and nutritional conditions which lead to the selection of thiaminase-producing strains cannot be reproduced experimentally. Moreover, high thiaminase activity had frequently been measured either in the rumen or in other parts of the digestive tract without associated 
pathological manifestations (Linklater et al. 1977; Grigat \& Mathison, 1982). In Europe, $\mathrm{CCN}$ is often associated with intensive feeding systems and high-concentrate diets which favour rumen acidogenic conditions (Tournut et al. 1967; Lusby \& Brent, 1972; Loew, 1975; Harmeyer \& Kollenkirchen, 1989).

Moreover, since 1982 it has been demonstrated that CCN can be induced by an excess of $S$ in the diet (Raisbeck, 1982; Gooneratne et al. 1989; Rousseaux et al. 1991; Hamlen et al. 1993; Low et al. 1996). It seems that CCN lesions can be induced by the direct action of sulfide or $\mathrm{H}_{2} \mathrm{~S}$ on the brain, as demonstrated recently by direct experimental administration of sulfide by McAllister et al. (1992). The role of sulfide is further emphasized by the fact that with high sulfate rations, the capacity of the rumen microflora to reduce sulfate to sulfide is increased (Cummings et al. 1995a,b). Interaction between the excess of dietary S and rumen thiamin production is controversial. In vitro, high levels of $\mathrm{S}$ can slightly increase the destruction of thiamin (Olkowski et al. 1993) but in vivo, in lambs, a high $\mathrm{S}$ diet $(6 \mathrm{~g} / \mathrm{kg} \mathrm{DM})$ did not induce any modification in rumen thiamin status (Alves de Oliveira et al. 1996). Thus, the aim of the present study was to investigate the effects of acidogenic conditions, a high $\mathrm{S}$ level and the possible interaction between these factors, on the microbial production of thiamin in the rumen. As measurement of the flux of thiamin at the duodenum is difficult under physiological conditions and not feasible in pathological ones, this study was conducted in vitro in a semi-continuous fermenter (RUSITEC) using semi-purified diets to allow a precise and independent manipulation of the different factors studied. As the microbial metabolism of thiamin is strongly modified by the dietary supply (Breves et al. 1981; Miller et al. 1986), both of these factors were tested in the presence or absence of added thiamin.

\section{MATERIALS AND METHODS}

\section{Fermentation system and experimental diets}

The effect of thiamin addition, acidogenic conditions and high $S$ level on rumen fermentation and microbial thiamin metabolism was investigated using the rumensimulating fermenter, RUSITEC (Czerkawski \& Breckenridge, 1977). It consisted of four plexiglass $1000 \mathrm{ml}$ vessels maintained at a constant temperature $\left(39^{\circ}\right)$. Inocula for the fermentation vessels $(500 \mathrm{ml}$ strained rumen fluid and $80 \mathrm{~g}$ solid material per vessel) were obtained from three rumen-fistulated sheep receiving a daily diet of $900 \mathrm{~g}$ chopped hay, $300 \mathrm{~g}$ barley, $10 \mathrm{~g}$ urea and $10 \mathrm{~g}$ mineral and vitamin $(\mathrm{A}, \mathrm{D}$, and $\mathrm{E})$ premix. The diet used in the RUSITEC consisted of a mixture of milled filter paper (Whatman International Ltd, Maidstone, Kent), pectins, xylan and starches (Table 1). The feed for the fermentation vessels $(14 \mathrm{~g}$ or $16.2 \mathrm{~g})$ was provided in nylon bags $(140 \times 120 \mathrm{~mm}$; mean pore size $150 \mu \mathrm{m}$ ) which were gently agitated in the liquid phase. The bags were divided into two compartments. The cellulosic component (paper) of the diet was introduced into one compartment and the powdered components (the other dietary carbohydrates) were introduced into the other part of the bag. Two double-bags were present in the vessels at any time and one double-bag was replaced each day to give a total of $48 \mathrm{~h}$ incubation for each bag. In addition, a bag of pre-digested straw was left inside the vessels throughout the experiment to act as a solid matrix for the slow-growing bacteria. The pre-digested straw was obtained by incubating straw contained within a nylon bag in the rumen of a sheep for $4 \mathrm{~d}$. After this period, the bag containing the straw was withdrawn, washed and dried at $55^{\circ}$ for $48 \mathrm{~h}$. The pre-digested straw was then introduced into new nylon bags before being placed in the vessels. 
Table 1. Daily input and composition of the two diets used in a rumen-simulating fermenter (RUSITEC) to study the effects of acidogenic conditions on fermentation end-products, microbial protein synthesis, sulfur and thiamin metabolism of ruminal micro-organisms

\begin{tabular}{lrr}
\hline \hline Acidogenic conditions*... & - & + \\
\hline Daily amount of diet (g) & 14 & $16 \cdot 2$ \\
Ingredients (g/kg) & 590 & 275 \\
Cellulose (paper Whatman† Chr. 3MM) & 70 & 75 \\
Xylan (Sigmał S0627) & 70 & 75 \\
Pectin (Sigmał P9135) & 200 & 500 \\
Wheat starch (Sigmał S5127) & 70 & 75 \\
Soluble starch (Prolabo\$ 21 152 291) & \\
\hline
\end{tabular}

* The dietary constituents and artificial saliva composition (Table 2$)$ were manipulated to simulate acidogenic $(+)$ and non-acidogenic $(-)$ conditions.

$\dagger$ Whatman International Ltd, Maidstone, Kent.

$\ddagger$ Sigma Chemical Co., St Louis, MO, USA.

$\S$ Prolabo, Fontenay sous Bois, France.

An artificial saliva was infused continuously into each vessel at a rate of $1000 \mathrm{ml} / \mathrm{d}$ to simulate saliva flow into the rumen and to provide a turnover of the liquid phase. The composition of the different artificial salivas was designed according to the factors being studied (Table 2). Urea, which was the only $\mathrm{N}$ source, was dissolved in the artificial saliva. A syringe pump (Vial médical, Becton Dickinson, Oxford) was used to perfuse $0.01 \mathrm{M}-\mathrm{HCl}$ solution at the rate of $9.4 \mathrm{ml} / \mathrm{d}$ into the fermenter. This solution was infused with or without $296 \mathrm{nmol}$ thiamin hydrochloride depending on the experimental design.

The liquid overflow (i.e. that displaced from the vessel) was collected in a cooled flask $\left(2^{\circ}\right)$ in order to stop microbial activity and preserve fermentation products. Fermentation gases were collected in glass cylinders containing $0.01 \mathrm{M}-\mathrm{HCl}$ to avoid gas loss. Each vessel was run for $7 \mathrm{~d}$ before the experimental period to allow adaptation and equilibration of the microbial population and all measurements were made during the last $5 \mathrm{~d}$ of the

Table 2. Composition of artificial salivas used in a rumen-simulating fermenter (RUSITEC) to study the effects of acidogenic conditions and high sulfur level on fermentation end-products, microbial protein synthesis, sulfur and thiamin metabolism of ruminal micro-organisms

\begin{tabular}{lcccr}
\hline \hline Acidogenic conditions*... & \multicolumn{2}{c}{-} & & + \\
\cline { 4 - 5 } High S level... & - & + & - & + \\
\hline Components $(\mathrm{g} / \mathrm{l}) \dagger$ & & & & \\
$\mathrm{NaHCO}_{3}$ & 9.240 & 9.240 & 6.470 & 6.470 \\
$\mathrm{Na}_{2} \mathrm{HPO}_{4} .12 \mathrm{H}_{2} \mathrm{O}$ & 7.120 & 7.120 & 4.980 & 4.980 \\
$\mathrm{Na}_{2} \mathrm{SO}_{4}$ & 0.133 & 0.333 & 0.151 & 0.377 \\
$\mathrm{NaCl}_{\text {Urea }}$ & 0.671 & 0.506 & 3.276 & 3.090 \\
\hline
\end{tabular}

* The artificial saliva composition and dietary constituents (Table 1$)$ were manipulated to simulate acidogenic $(+)$ and non-acidogenic $(-)$ conditions.

† For all solutions; major minerals $(\mathrm{g} / \mathrm{l}): \mathrm{CaCl}_{2} \cdot 2 \mathrm{H}_{2} \mathrm{O} 0.073, \mathrm{MgCl}_{2} \cdot 6 \mathrm{H}_{2} \mathrm{O} 0 \cdot 100, \mathrm{KCl} 0.45$; trace elements (mg/l): $\mathrm{FeCl}_{2} \cdot 4 \mathrm{H}_{2} \mathrm{O} \quad 20 \cdot 5, \quad \mathrm{MnCl}_{2} .4 \mathrm{H}_{2} \mathrm{O} \quad 22 \cdot 15, \mathrm{ZnSO}_{4} \cdot 7 \mathrm{H}_{2} \mathrm{O} \quad 4.4, \mathrm{CoCl}_{2} \cdot 6 \mathrm{H}_{2} \mathrm{O} \quad 1.2, \quad \mathrm{CuSO}_{4} .5 \mathrm{H}_{2} \mathrm{O} \quad 0.98, \quad \mathrm{Mo}_{7}$ $\left(\mathrm{NH}_{4}\right)_{6} \mathrm{O}_{24} \cdot 4 \mathrm{H}_{2} \mathrm{O} 0 \cdot 174$; growth factors and vitamins $(\mathrm{mg} / 1)$ : valine 11 , leucine 13 , isoleucine 13 , cyanocobalamin 0.5 , biotin $0.01, p$-aminobenzoic acid 0.2 , pteroylglutamic acid 0.05 , pyridoxine 2 , pantothenic acid 2 , riboflavin 2 , phylloquinone $0 \cdot 1$, niacin 2 , choline 75 . 
experiment. The $\mathrm{pH}$ of fermentation fluid was recorded continuously. Samples of fermentation fluid $(2.5 \mathrm{ml})$ were withdrawn twice daily $6 \mathrm{~h}$ after the introduction of the solid substrate $(T+6 h)$ and just before the daily renewal of the substrate $(T+24 h)$.

\section{Analytical procedures}

Liquid overflow was analysed for $\mathrm{pH}$ using a $\mathrm{pH}$-meter (Ionoproc, Radiometer Analytical, Villeurbanne, France), short-chain fatty acids (SCFA) by a GC method described by Jouany (1982) and lactic acid by an enzymic procedure (Gutmann \& Wahlefeld, 1974). Urea and $\mathrm{NH}_{3}-\mathrm{N}$ were measured by the colorimetric methods of Bousquet et al. (1971) and Weatherburn (1967) respectively, and sulfate by the method of Sorbö (1987). The volume of the overflow, together with the concentration of fermentation products, was used to calculate the daily output of fermentation products.

The fermented organic matter (FOM) was calculated from the daily output of SCFA (expressed in mol) using a formula derived by Demeyer \& van Nevel (1979):

$$
\operatorname{FOM}(\mathrm{g} \text { hexose })=(\mathrm{Ac} / 2+\mathrm{Pro} / 2+\mathrm{But}+\mathrm{Val}+\text { Isoval + Capr }) \times 162,
$$

where Ac is acetate, Pro is propionate, But is butyrate, Val is valerate, Isoval is isovalerate and Capr is caproate.

Total $N\left(N_{t}\right)$ was determined by the Kjeldahl method both on bag feed residues and on liquid overflow. $\mathrm{N}$ incorporated by the microflora $\left(\mathrm{N}_{\mathrm{m}}\right)$ was estimated by the difference between total $\mathrm{N}$ (liquid overflow plus bag feed residue) and $\mathrm{NH}_{3}$ plus urea $\mathrm{N}$ :

$$
\mathrm{N}_{\mathrm{m}}=\mathrm{N}_{\mathrm{t}}-\left(\mathrm{N}_{\mathrm{NH}_{3}}+\mathrm{N}_{\text {urea }}\right) \text {. }
$$

Sulfide in samples of fermenter fluid was determined by the method of Cline (1969).

The gas volumes were measured by liquid displacement and samples were analysed for $\mathrm{CH}_{4}, \mathrm{CO}_{2}$ and $\mathrm{H}_{2}$ by $\mathrm{GC}$, with $\mathrm{Ar}$ as the carrier gas (Manka, 1964).

The DM of paper in incubated bags and in samples of non-incubated paper was determined by drying at $80^{\circ}$ for $48 \mathrm{~h}$ and used to calculate the digestibility of the dietary fibre component at $48 \mathrm{~h}$ taking into account the DM remaining in the corresponding bag compartment. The bag compartment containing all the other dietary carbohydrates was always empty.

Thiamin and thiamin phosphate esters were determined on liquid overflow and onbag feed residues by HPLC, using post-column derivatization and fluorescence detection of the fluorophores (excitation: $366 \mathrm{~nm}$; emission: $434 \mathrm{~nm}$ ). Samples of liquid overflow and bag feed residues were immediately acidified to $\mathrm{pH} 1.6$ with $\mathrm{HCl}$, vigorously shaken and frozen at $-20^{\circ}$. Just before analysis the thawed samples were shaken and filtered through a $0.45 \mu \mathrm{m}$ cellulose acetate filter (Minisart, Sartorius, Göttingen, Germany). A portion $(100 \mu \mathrm{l})$ of filtrate was injected in a Lichrospher $10 \mu \mathrm{m} \mathrm{C}_{18}$ column $(4 \times 250 \mathrm{~mm}$, Interchim, Montluçon, France) equipped with a $C_{18}$ guard column $(4 \times 4 \mathrm{~mm})$ and eluted using an isocratic pump at a flow rate of $0.9 \mathrm{ml} / \mathrm{min}$. The addition of $2.5 \mathrm{mM}$-potassium ferricyanide in $3 \mathrm{M}-\mathrm{NaOH}$ solution, with a post-column isocratic pump $(0.12 \mathrm{ml} / \mathrm{min})$, converted thiamin and thiamin phosphate esters into fluorophores. The complete determination of thiamin compounds was performed in two runs. In the first run thiamin pyrophosphate (TPP) and thiamin monophosphate (TMP) were eluted using a mobile phase (methanol-42 mM-sodium citrate buffer $(35: 65$, v/v), $\mathrm{pH} 4$ ) containing $10 \mathrm{mM}$-decanesulfonate. Free thiamin was eluted during the second run using a second mobile phase (methanol-42 mM-sodium citrate buffer $(65: 35, \mathrm{v} / \mathrm{v}), \mathrm{pH} 3.7)$ containing $10 \mathrm{mM}$ decanesulfonate. 
Total thiaminase activity (thiaminase I, EC 2.5.1.2 and thiaminase II, EC 3.5.99.2) in the liquid overflow was determined using a technique adapted from Thomas (1986), with a buffer containing $18 \mathrm{mM}$-sodium citrate and $82 \mathrm{mM}$-disodium phosphate at a $\mathrm{pH}$ of 6.5 , $0.5 \mathrm{mM}-{ }^{14} \mathrm{C}$ thiazole-labelled thiamin as substrate and $100 \mathrm{mM}$-pyridine as co-substrate. One unit of thiaminase activity corresponded to the formation of $1 \mu \mathrm{mol}$ thiazole/min per $\mathrm{ml}$.

\section{Experimental design and statistical analysis}

Three factors were studied. The first factor was thiamin addition. Half of the fermenters were unsupplemented and the others received $296 \mathrm{nmol}$ thiamin hydrochloride by day.

The second factor studied was acidogenic conditions. 'Acidogenic conditions' was defined as the sum of several experimentally-induced factors intended to reproduce chronic acidosis in the fermenters. Acidogenic conditions were obtained by simultaneously feeding $16.2 \mathrm{~g} / \mathrm{d}$ of a high-starch diet (Table 1) and infusing artificial saliva in which the buffer salts had been reduced by $30 \%$ (Table 2). Control $\mathrm{pH}$ conditions were obtained by feeding 14 $\mathrm{g} / \mathrm{d}$ of a low-starch diet (Table 1) and infusion of a control artificial saliva (Table 2). Consequently, the two diets differed, on one hand by the amount of DM used, on the other hand by the starch : cellulose ratio, which was 0.46 in the low-starch diet and 2.09 in the high-starch diet.

The third factor studied was the amount of $S$. The low $S$ level corresponded to $2 \mathrm{~g} / \mathrm{kg}$ and the high $\mathrm{S}$ level to $5 \mathrm{~g} / \mathrm{kg}$ dietary DM. S was provided in the form of $\mathrm{Na}_{2} \mathrm{SO}_{4}$ dissolved in the artificial saliva (Table 2).

Each factor studied had two levels. The lowest level $(-1)$ corresponded to the absence of added thiamin, control $\mathrm{pH}$ conditions, and control $\mathrm{S}$ level, the highest one $(+1)$ to added thiamin, acidogenic conditions, and high $\mathrm{S}$ level. The combination of these three factors gave eight treatments and all treatment combinations were evaluated in two replicate vessels. Each vessel was considered as an experimental unit. It was impossible to run all the treatments within the same period with only four vessels. Thus, two replicates of a $2^{3}$ factorial design were arranged in four periods with four fermenters used for each period. For all periods, the inoculum was provided by the same group of donor sheep.

Results were compared using a factorial model to determine the effect of thiamin addition, acidogenic conditions, high $S$ level and interactions between added thiamin $\times$ acidogenic conditions, added thiamin $\times$ high $S$ level and acidogenic conditions $\times$ high $S$ level. There were two 'block factors' in this experiment, period and vessel, which were crossed. The interaction effect between $\mathrm{pH}$ and $\mathrm{S}$ was confounded, with one degree of freedom associated with the vessel 'block factor'. The main effects and the other twofactor interactions were unconfounded with blocks.

The model used was:

$$
\begin{aligned}
y_{i j}=\mu+\alpha 1 \times \mathrm{B} 1+\alpha 2 \times \mathrm{pH}+\alpha 3 \times \mathrm{S}+\alpha 4 \times \mathrm{B} 1 \times \mathrm{pH}+ \\
\alpha 5 \times \mathrm{B} 1 \times \mathrm{S}+\alpha 6 \times \mathrm{pH} \times \mathrm{S}+V i+P j+\varepsilon_{i j},
\end{aligned}
$$

where $y_{i j}$ is a response of interest, $\mu$ is an intercept and $\mathrm{B} 1, \mathrm{pH}, \mathrm{S}$ are +1 or -1 coded levels of the factors. The values $\alpha 1, \alpha 2, \ldots \alpha 6$, are the factorial main effects and interaction effects, $V i$ is the vessel $i$ effect $(i=1,2,3,4), P j$ is the period $j$ effect $(j=1,2,3,4)$ and $\varepsilon_{i j}$ is the random error. The $\mathrm{pH} \times \mathrm{S}$ interaction, which was a between-vessel effect, was tested against the vessel term. The other effects were tested against the error. Calculations were made using the general linear models (GLM) procedure of SAS Institute Inc. (Statistical Analysis Systems, 1985). 


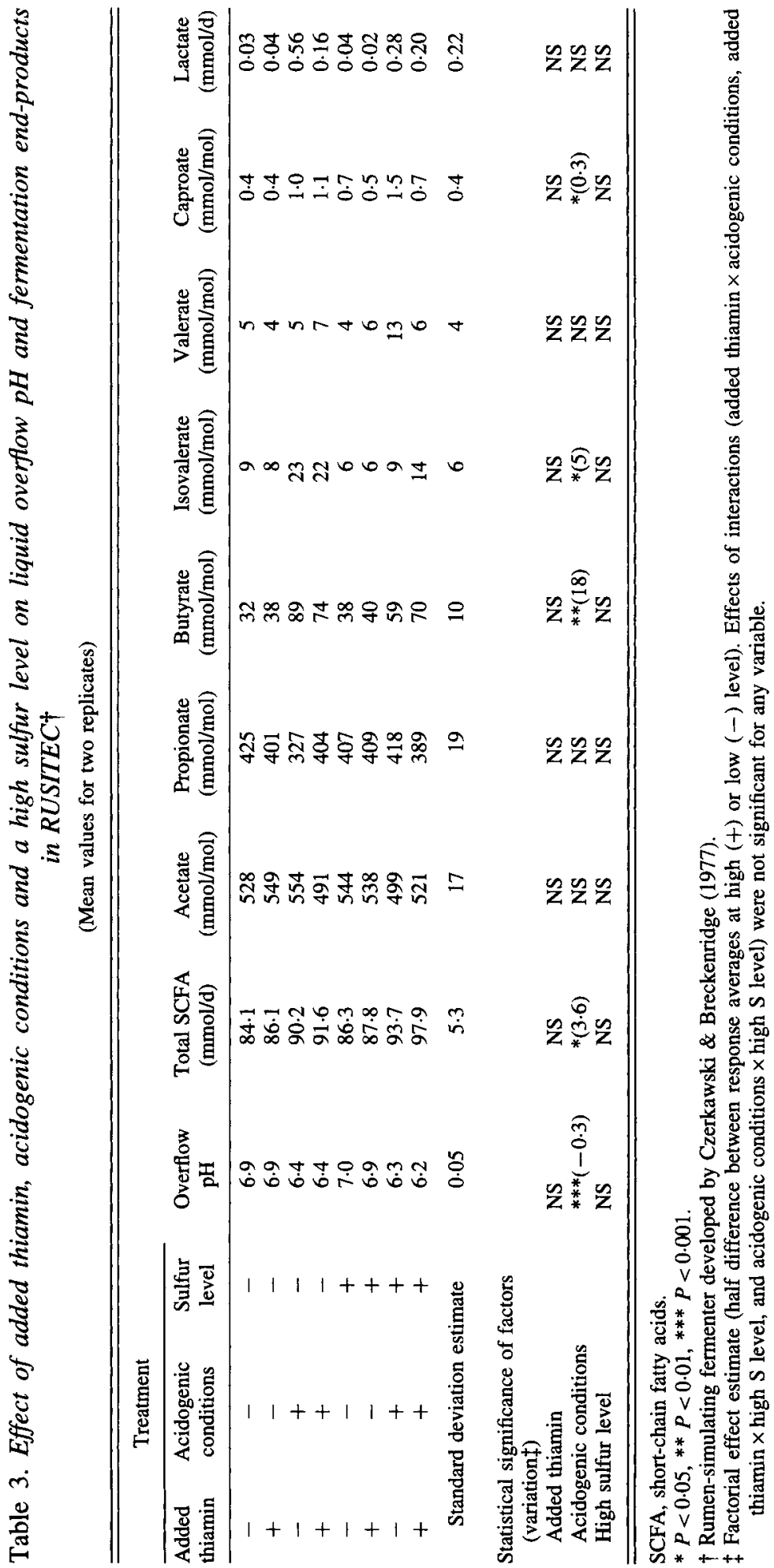


Table 4. Effect of added thiamin, acidogenic conditions and a high sulfur level on daily output of fermentation gases, fermented organic matter (FOM), microbial nitrogen incorporation $(\mathrm{Nm})$, microbial yield and cellulose DM degradation in RUSITEC $\dagger$

(Mean values for two replicates)

\begin{tabular}{|c|c|c|c|c|c|c|c|c|c|}
\hline \multicolumn{3}{|c|}{ Treatment } & \multirow[b]{2}{*}{$\begin{array}{c}\mathrm{CO}_{2} \\
(\mathrm{mmol} / \mathrm{d})\end{array}$} & \multirow[b]{2}{*}{$\begin{array}{c}\mathrm{CH}_{4} \\
(\mathrm{mmol} / \mathrm{d})\end{array}$} & \multirow[b]{2}{*}{$\begin{array}{c}\mathrm{H}_{2} \\
(\mathrm{mmol} / \mathrm{d})\end{array}$} & \multirow[b]{2}{*}{$\begin{array}{l}\text { FOM } \\
(\mathrm{g} / \mathrm{d})\end{array}$} & \multirow[b]{2}{*}{$\underset{(\mathrm{mg} / \mathrm{d})}{\mathrm{Nm}}$} & \multirow[b]{2}{*}{$\begin{array}{c}\text { Nm/FOM } \\
(\mathrm{mg} / \mathrm{g})\end{array}$} & \multirow[b]{2}{*}{$\begin{array}{l}\text { Cellulose } \\
\text { DMD (\%) }\end{array}$} \\
\hline Added thiamin & $\begin{array}{l}\text { Acidogenic } \\
\text { conditions }\end{array}$ & $\begin{array}{l}\text { Sulfur } \\
\text { level }\end{array}$ & & & & & & & \\
\hline- & - & - & $105 \cdot 3$ & 14.8 & 0.1 & $7 \cdot 1$ & 222 & 31.7 & $66 \cdot 4$ \\
\hline+ & - & - & 109.8 & $16 \cdot 7$ & $0 \cdot 1$ & $7 \cdot 3$ & 230 & 31.9 & 67.0 \\
\hline- & + & - & 96.5 & $10 \cdot 2$ & 0.4 & $8 \cdot 2$ & 241 & $30 \cdot 2$ & $20 \cdot 6$ \\
\hline+ & + & - & $109 \cdot 6$ & 15.6 & 0.4 & $8 \cdot 2$ & 276 & 33.9 & 37.4 \\
\hline- & - & + & $103 \cdot 1$ & $15 \cdot 1$ & 0.1 & $7 \cdot 3$ & 234 & 32.6 & 70.5 \\
\hline+ & - & + & $102 \cdot 7$ & 14.8 & 0.2 & 7.5 & 229 & $31 \cdot 2$ & 75.9 \\
\hline- & + & + & 100.7 & 8.4 & 1.2 & 8.2 & 255 & 31.8 & 23.9 \\
\hline+ & + & + & 110.7 & 11.0 & 0.7 & $8 \cdot 6$ & 247 & 29.6 & $52 \cdot 5$ \\
\hline \multicolumn{3}{|c|}{ Standard deviation estimate } & 8.6 & 1.7 & $0 \cdot 3$ & 0.5 & 13 & 0.6 & $10 \cdot 4$ \\
\hline \multicolumn{10}{|c|}{$\begin{array}{l}\text { Statistical significance of factor } \\
\text { (variation } \neq \text { ) }\end{array}$} \\
\hline \multicolumn{3}{|c|}{ Added thiamin } & NS & NS & NS & NS & NS & NS & NS \\
\hline \multicolumn{3}{|c|}{ Acidogenic conditions } & NS & $* *(-2.0)$ & $*(0 \cdot 3)$ & $*(0.5)$ & $*(13)$ & NS & $* *(-18 \cdot 6)$ \\
\hline \multicolumn{3}{|c|}{ High sulfur level } & NS & NS & NS & NS & NS & NS & NS \\
\hline
\end{tabular}

$* P<0.05, * * P<0.01$.

$\dagger$ Rumen-simulating fermenter developed by Czerkawski \& Breckenridge (1977).

$\ddagger$ Factorial effect estimate (half difference between response averages at high $(+)$ or low (-) level). Effects of interactions (added thiamin $\times$ acidogenic conditions, added thiamin $\times$ high $S$ level, and acidogenic conditions $\times$ high $S$ level) were not significant for any variable except for added thiamin $\times$ high $S$ level interaction for Nm/ FOM $(P<0.01)$.

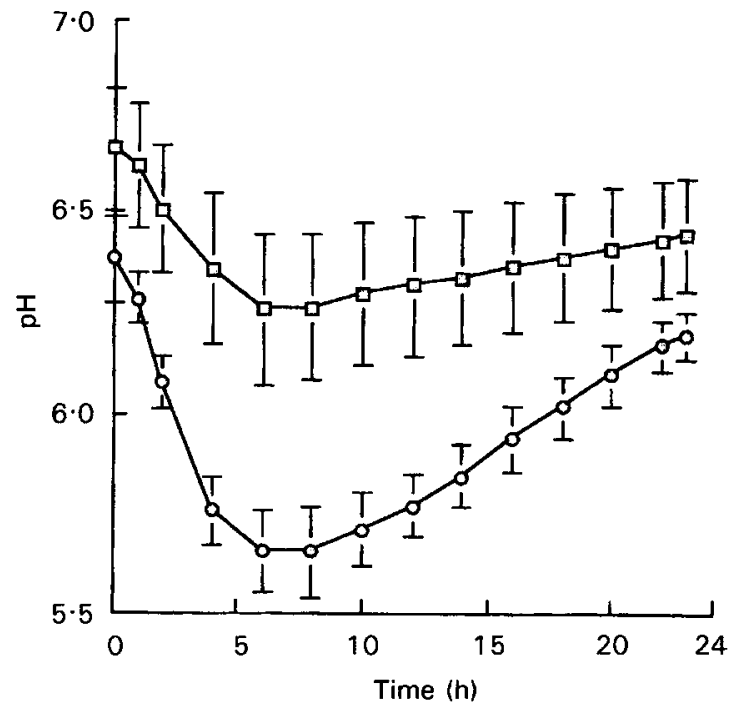

Fig. 1. Daily variation in pH of fermenter liquid phase under control $(\square)$ and acidogenic $(O)$ conditions in a rumensimulating fermenter (RUSITEC). 


\section{RESULTS}

\section{Effect of acidogenic conditions, high sulfur level and added thiamin on $p H$ and fermentation end-products}

Acidogenic conditions had a marked effect on the $\mathrm{pH}$ and on microbial metabolism (Tables 3 and 4 ). The $\mathrm{pH}$ of the liquid overflow was decreased by 0.62 unit. The diurnal variation in the $\mathrm{pH}$ of the vessel contents was also modified (Fig. 1). A pH decrease was observed after the re-feeding of the vessels, the lowest $\mathrm{pH}$ being observed after $\mathrm{T}+6 \mathrm{~h}$. This was more marked under acidogenic conditions $(-0.78$ unit) than in the control ones $(-0.40$ unit). SCFA production and FOM increased by $7.3 \mathrm{mmol} / \mathrm{d}$ and $1.02 \mathrm{~g} / \mathrm{d}$ respectively under acidogenic conditions but the molar ratio of SCFA was not modified with the exception of consistent increases in butyrate $(73 v .37 \mathrm{mmol} / \mathrm{mol})$, isovalerate $(17 v .7 \mathrm{mmol} / \mathrm{mol})$ and caproate $(1.1$ v. $0.5 \mathrm{mmol} / \mathrm{mol})$ concentrations. Gas production was also modified, $\mathrm{CH}_{4}$ production decreasing by $26 \%$ under acidogenic conditions with a concomitant increase in $\mathrm{H}_{2}$ production being noted. Acidogenic conditions considerably decreased $(-37 \%)$ the digestibility of cellulose. $\mathrm{N}_{\mathrm{m}}$ was increased by $11.4 \%$ but the $\mathrm{N}_{\mathrm{m}}: \mathrm{FOM}$ ratio was not modified. $\mathrm{NH}_{3}$ concentrations remained in the range $150-210 \mathrm{mg} / \mathrm{l}$, assumed to be adequate to satisfy microbial requirements.

The high $\mathrm{S}$ level and thiamin addition did not modify any of the variables mentioned. thiamin.

No interaction was noted between acidogenic conditions, high $S$ level and added

Table 5. Effect of added thiamin, acidogenic conditions and a high sulfur level on the daily sulfate overflow and on the fermenter fluid sulfide concentration in RUSITEC $\dagger$

(Mean values for two replicates)

\begin{tabular}{|c|c|c|c|c|c|}
\hline \multicolumn{3}{|c|}{ Treatment } & \multirow{2}{*}{$\begin{array}{l}\text { Sulfate } \\
\text { liquid } \\
\text { overflow } \\
(\mathrm{mmol} / \mathrm{d})\end{array}$} & \multirow{2}{*}{$\begin{array}{c}\text { Sulfide } \\
\text { fermenter } \\
\mathrm{T}+6 \mathrm{~h} \ddagger \\
(\mathrm{mmol} / \mathrm{)})\end{array}$} & \multirow{2}{*}{$\begin{array}{c}\text { Sulphide } \\
\text { fermenter } \\
\mathrm{T}+24 \mathrm{~h}_{\ddagger}^{\dagger} \\
(\mathrm{mmol} / \mathrm{l})\end{array}$} \\
\hline Added thiamin & $\begin{array}{l}\text { Acidogenic } \\
\text { conditions }\end{array}$ & Sulfur level & & & \\
\hline- & - & - & 0.05 & 0.14 & $0 \cdot 27$ \\
\hline+ & - & - & 0.08 & $0 \cdot 13$ & 0.35 \\
\hline- & + & - & 0.24 & 0.10 & 0.27 \\
\hline+ & + & - & 0.09 & 0.07 & 0.20 \\
\hline- & - & + & 0.12 & 0.80 & $1 \cdot 12$ \\
\hline+ & - & + & 0.05 & 0.58 & 0.83 \\
\hline- & + & + & 0.08 & 0.51 & 0.90 \\
\hline+ & + & + & $0 \cdot 10$ & 0.72 & $1 \cdot 14$ \\
\hline \multicolumn{3}{|c|}{ Standard deviation estimate } & 0.07 & 0.07 & 0.06 \\
\hline \multicolumn{6}{|c|}{ Statistical significance of factors (variation§) } \\
\hline \multicolumn{3}{|c|}{ Added thiamin } & NS & NS & NS \\
\hline \multicolumn{3}{|c|}{ Acidogenic conditions } & NS & NS & NS \\
\hline \multicolumn{3}{|c|}{ High sulfur level } & NS & $* * *(0.27)$ & $* * *(0.36)$ \\
\hline
\end{tabular}

*** $P<0.001$.

$\dagger$ Rumen-simulating fermenter developed by Czerkawski \& Breckenridge (1977).

$\ddagger 6$ or $24 \mathrm{~h}$ after substrate bag renewal.

$\S$ Factorial effect estimate (half difference between response averages at high $(+)$ or low $(-)$ level). Effect of interactions (added thiamin $\times$ acidogenic conditions, added thiamin $\times$ high $S$ level, and acidogenic conditions $\times$ high $S$ level) were not significant for any variable. 


\section{Effect of acidogenic conditions, high sulfur level and added thiamin on the microbial metabolism of sulfate}

Results for the effect of changes in conditions in the fermenters on microbial metabolism of sulfate are shown in Table 5. Sulfide production was very active and increased with the amount of sulfate used. Residual amounts of sulfate in liquid overflow were low and did not differ significantly between control and high $\mathrm{S}$ levels.

Total daily production of sulfide collected in gas and liquid overflow was on average five times higher when the high level of $S$ was infused $(0.14 v .0 .68 \mathrm{mmol} / \mathrm{d})$. In all vessels, sulfide concentration varied during the day and was lower at $\mathrm{T}+6 \mathrm{~h}$ compared with $\mathrm{T}+24 \mathrm{~h}$. In vessels infused with a high level of $\mathrm{S}$, sulfide concentration was 5.9 and 3.6 times greater after $6 \mathrm{~h}$ and $24 \mathrm{~h}$ respectively compared with that in control vessels.

Acidogenic conditions and thiamin addition had no significant effects on sulfate and sulfide concentrations.

\section{Effect of added thiamin, acidogenic conditions and sulfur excess on thiamin metabolism}

Results for the effect of changes in conditions in the fermenters on thiamin metabolism are shown in Table 6. The net thiamin production in this experiment was defined as the difference between total thiamin output minus added thiamin. This net thiamin production

Table 6. Effect of added thiamin, acidogenic conditions and a high sulfur level on total thiamin output, proportions of phosphorylated or free forms of thiamin ouput, net thiamin synthesis and thiaminase activity in RUSITEC $\dagger$

(Mean values for two replicates)

\begin{tabular}{|c|c|c|c|c|c|c|c|c|}
\hline \multicolumn{3}{|c|}{ Treatment } & \multirow{2}{*}{$\begin{array}{l}\text { Total } \\
\text { thiamin output } \\
(\mathrm{nmol} / \mathrm{d})\end{array}$} & \multirow[b]{2}{*}{$\begin{array}{l}\text { TPP } \\
(\%)\end{array}$} & \multirow[b]{2}{*}{$\begin{array}{l}\text { TMP } \\
(\%)\end{array}$} & \multirow{2}{*}{$\begin{array}{c}\text { Free } \\
\text { thiamin } \\
(\%)\end{array}$} & \multirow{2}{*}{$\begin{array}{l}\text { Net } \\
\text { thiamin } \\
\text { synthesis } \\
\text { (nmol/d) }\end{array}$} & \multirow{2}{*}{$\begin{array}{c}\text { Thiaminase } \\
\text { activity } \\
\text { (mU })\end{array}$} \\
\hline $\begin{array}{l}\text { Added } \\
\text { thiamin }\end{array}$ & $\begin{array}{l}\text { Acidogenic } \\
\text { conditions }\end{array}$ & $\begin{array}{l}\text { Sulfur } \\
\text { level }\end{array}$ & & & & & & \\
\hline- & - & - & 334 & 84.9 & 9.5 & 5.6 & 334 & 0.02 \\
\hline+ & - & - & 442 & $81 \cdot 3$ & 9.1 & 9.5 & $146 \S$ & 0.05 \\
\hline- & + & - & 319 & 88.9 & 7.7 & 3.4 & 319 & 0.03 \\
\hline+ & + & - & 496 & 73.6 & 9.6 & 16.7 & $200 \S$ & 0.01 \\
\hline- & - & + & 250 & 89.1 & $8 \cdot 7$ & $2 \cdot 2$ & 250 & 0.04 \\
\hline+ & - & + & 416 & $84 \cdot 1$ & $10 \cdot 0$ & 5.8 & $120 \S$ & 0.02 \\
\hline- & + & + & 282 & $90 \cdot 2$ & $5 \cdot 5$ & $4 \cdot 2$ & $282^{\circ}$ & 0.01 \\
\hline+ & + & + & 396 & $88 \cdot 3$ & 6.7 & 4.9 & $100 \S$ & 0.01 \\
\hline \multicolumn{3}{|c|}{ Standard deviation estimate } & 25 & $2 \cdot 8$ & $1 \cdot 1$ & $2 \cdot 6$ & 25 & 0.01 \\
\hline \multicolumn{9}{|c|}{$\begin{array}{l}\text { Statistical significance of factor } \\
\quad(\text { variation } \|)\end{array}$} \\
\hline \multicolumn{3}{|c|}{ Added thiamin } & $* * *(70)$ & $*(-3.2)$ & NS & $*(2 \cdot 7)$ & $* * *(-77)$ & NS \\
\hline \multicolumn{3}{|c|}{ Acidogenic conditions } & NS & NS & $*(-1.0)$ & NS & NS & NS \\
\hline \multicolumn{3}{|c|}{ High sulfur level } & $* *(-31)$ & $*(2 \cdot 9)$ & NS & $*(-2 \cdot 2)$ & $*(-31)$ & NS \\
\hline
\end{tabular}

TPP, thiamin pyrophosphate; TMP, thiamin monophosphate.

$* P<0.05, * * P<0.01$, *** $P<0.001$.

† Rumen-simulating fermenter developed by Czerkawski \& Breckenridge (1977).

$\ddagger \mathrm{mU}=\mathrm{nmol}$ thiazole/min per $\mathrm{ml}$.

$\S$ Total thiamin minus $296 \mathrm{nmol}$ thiamin added.

I| Factorial effect estimate (half difference between response averages at high (+) or low (-) level). Effects of interactions (added thiamin $\times$ acidogenic conditions, added thiamin $\times$ high $S$ level, and acidogenic conditions $\times$ high $S$ level) were not significant for any variable. 
decreased considerably with the external addition of thiamin. In addition, the proportion of TPP decreased slightly but with a concomitant increase in the proportion of free thiamin. In contrast no significant difference was found in the proportion of TMP between vessels with and without added thiamin.

Acidogenic conditions had no effect on thiamin production irrespective of other conditions tested. In contrast, an excess of $S$ decreased thiamin production. When no external thiamin was added, total or net thiamin production decreased from 326 to $266 \mathrm{nmol} / \mathrm{d}$. When external thiamin was added, total thiamin production decreased from 469 to $406 \mathrm{nmol} / \mathrm{d}$ and net thiamin production decreased from 173 to $110 \mathrm{nmol} / \mathrm{d}$.

Thiaminase activity was not significantly influenced by the different treatments. No significant interaction in relation to thiamin metabolism was found between acidogenic conditions and the high level of $S$.

\section{DISCUSSION}

\section{Chronic acidosis in vitro model}

As CCN appears essentially in chronically acidotic animals, our objective was to reproduce chronic rumen acidosis conditions in a rumen simulation in vitro system (RUSITEC). In vivo, chronic acidosis may be observed in animals exposed to high-concentrate diets. This usually results in a modified rumen microbial equilibrium which can reach a steady state, unlike acute lactic acidosis which is characterized by a sudden and dramatic ecological imbalance.

The conditions used to induce chronic acidosis in this experiment were evaluated in preliminary studies taking into consideration the main risk factors found in farming situations, namely high DM intake, high concentrate: forage ratio, and low saliva flow resulting in lowered rumen buffering capacity. Purified substrates were used because they increased reproducibility in different periods compared with natural concentrate diets, and also because it is easier to achieve an accurate measurement of microbial thiamin synthesis with a thiamin-free diet.

The experimental conditions applied to simulate chronic acidosis resulted in a significant reduction of the daily average $\mathrm{pH}$ and in a postprandial $\mathrm{pH}$ decrease. This simulated the rumen $\mathrm{pH}$ variation after a meal, and differed from most previous in vitro studies, where low rumen $\mathrm{pH}$ was generally achieved by the use of a continuous $\mathrm{pH}$ control system (Erflé et al. 1982; Shi \& Weiner, 1992). SCFA production was increased but lactate accumulation was not observed. The same phenomenon was observed in vivo, in chronic acidotic animals, adapted for a long time to a high-concentrate diet (Nakamura et al. 1989; Murphy, 1993). This may have been due to the absence of soluble sugars and protein $\mathrm{N}$ in the experimental diet which decreased the risk of high lactic acid production, as discussed by Counotte \& Prins (1981). These authors also stressed the importance of an adaptation time to the ruminal metabolism of lactate in animals fed on carbohydrate-rich diets. The development of an efficient lactate-fermenting population was achieved rapidly in the RUSITEC as a steady state without lactate in the fermentation products was obtained within $7 \mathrm{~d}$. The absence of lactate, associated with an increase in butyrate and caproate, may be explained by the presence of Megasphaera elsdenii, the major ruminal lactolytic bacterium as already described in vitro by Erflé et al. (1982). However, as the acetate : propionate ratio was not modified, lactate metabolism in the model may have been driven by a more complex lactate-fermenting population, resulting in both acetate and propionate as lactate transformation products. 
It must be taken into consideration that in our experiment, the acetate : propionate ratio was already low under control conditions. This had previously been observed when purified and protein-free diets were used in a similar RUSITEC system (M. Durand, personal communication) and under both in vitro (batch) and in vivo conditions by Kumaresan (1976). The use of pure cellulose, which may be more rapidly and extensively degraded than ligno-cellulose, might have enhanced some cellulolytic strains (Fibrobacter succinogenes, Ruminococcus flavefaciens) producing succinate as a major end-product (Miller, 1978). The symbiotic association with a succinate user (Selenomonas ruminantium) could then explain the large amount of propionate found in SCFA, as succinate decarboxylation is a major propionate-producing pathway in the rumen (Wolin \& Miller, 1983).

The decreases in $\mathrm{CH}_{4}$ production and cellulose digestibility obtained under acidogenic conditions are typical signs of acidosis. The methanogenic and cellulolytic bacteria are known to be very $\mathrm{pH}$ sensitive and growth and activity start to decline significantly at $\mathrm{pH}$ values below 6. The microbial yield (Nm/FOM) was not affected by acidosis under our experimental conditions. This is compatible with a chronic acidotic state and the low lactate production in the model. Indeed, a decrease in microbial yield has been reported when acute lactic acidosis occurs and it was attributed to the low ATP yield when sugar was catabolized to lactate (Hoover et al. 1984).

In general, acidogenic conditions induced in the RUSITEC system led to an in vitro model which was considered suitable for use in studies of chronic acidosis.

\section{High sulfur level and ruminal metabolism}

Sulfate-reducing bacteria can be divided into two groups: assimilatory and dissimilatory organisms. Sulfide produced by the former is incorporated into S-containing amino acids and proteins. The latter group utilizes sulfate both to synthesize protein and as a final electron acceptor in ATP generation processes. The dissimilatory reducing pathway produces high amounts of sulfide which are released into the rumen liquid phase.

The amount of $S(2 \mathrm{~g} / \mathrm{kg})$ and the $\mathrm{N}: \mathrm{S}$ ratio $(15: 1)$ of the diet in control vessels were tested previously to ensure that they satisfied microbial requirements under our experimental conditions. In control vessels, sulfide concentrations were low and within the range of in vivo values $(0 \cdot 07-0.35 \mathrm{mmol} / \mathrm{l})$ observed with dietary $\mathrm{S}$ levels close to the animal's requirements (Bray, 1964; Qi et al. 1993).

The high $\mathrm{S}$ level did not modify rumen microbial protein synthesis. Thus, it can be concluded that the assimilatory sulfate-reducing pathway was not modified. In high-S vessels, residual sulfate was low and the amount of sulfide rose to as much as four times the control sulfide level, indicating that a dissimilatory sulfate-reducer population was established in the system. According to Cummings et al. $(1995 a, b)$ the capacity to generate $\mathrm{H}_{2} \mathrm{~S}$ from sulfate in steers only increased after 10-12 d of feeding a high-sulfate diet. In the RUSITEC, $7 \mathrm{~d}$ of adaptation were enough to reach a high sulfide production capacity. The sulfide concentrations achieved were within the range of those observed in vivo after adaptation to higher-S diets. No interaction between the high $S$ level and acidogenic conditions was noted and this is in accord with the findings of Kandylis (1984), that mild $\mathrm{pH}$ variations tend not to increase sulfate reduction.

The high $S$ level applied to the vessels had almost no significant effect on rumen fermentation variables. This result is in agreement with in vitro observations made by Hubbert et al. (1958) and Kennedy et al. (1971) and made in in vivo trials by Johnson et al. (1968), Rumsey (1978), and Alves de Oliveira et al. (1996). The S level was not high 
enough to shift, significantly, $\mathrm{H}$ utilization from methanogenesis to sulfide production, as the amount of $\mathrm{CH}_{4}$ was not lowered by the high $\mathrm{S}$ level. Thus, sulfide concentration in the fermenter had no deleterious effect on the microbial utilization of dietary energy and nonprotein $\mathbf{N}$.

\section{Ruminal thiamin metabolism}

Net thiamin production in the RUSITEC was within the range observed in vivo (4-17 $\mu \mathrm{g}$ vitamin $\mathrm{B}_{1} / \mathrm{g}$ organic matter apparently degraded in the rumen) in sheep (Breves et al. 1980) or in cows (Steinberg \& Kaufmann, 1977; Breves et al. 1981). This indicated that long-term fermentation systems are more effective than short duration models, where no net thiamin production was observed (Olkowski et al. 1993).

A number of clinical observations made internationally all strengthen the theory that high-concentrate diets and associated acidosis are major risk factors for the development of CCN. Acidogenic conditions applied to the RUSITEC, alone or in combination with an excess of S, had no effect on thiamin production. Moreover, no variation of thiaminase activity was noted. This must be examined carefully as the production of thiaminases in the rumen is considered a key point in the hypothesis generally made about the aetiology of CCN (Brent \& Bartley, 1984). In our present experiment, the thiaminase activity measured was low and only of the order of approximately 0.1 unit thiaminase activity measured in ruminal fluid of inoculum donor sheep. This indicates that neither thiaminase I nor thiaminase II was effective in inactivating the thiamin. It can be concluded that a moderate $\mathrm{pH}$ decrease (not below 5.5 under our experimental conditions) has no effect, either on the production of thiaminases by rumen bacteria, or on the selection of strains producing high levels of these enzymes. Nevertheless, it must be emphasized that the nature of the thiaminase-producing strains is a controversial point. Among the usual bacterial species, Megasphaera elsdenii, which consume lactic acid, could be an important source of thiaminase (Boyd, 1985). Despite the very low thiaminase activity, the presence of this species in RUSITEC was suspected as it can multiply within the $\mathrm{pH}$ range of 5.5-6.5 (Russell \& Dombrowski, 1980). However, a high thiaminase activity has been attributed to species like Bacillus thiaminolyticus (Morgan \& Lawson, 1974) or Clostridium sporogenes (Shreeve \& Edwin, 1974) which are not usual constituents of the rumen microbial population. In this sense, the in vitro model is limited as it does not take into account accidental contamination by such species. There was no evidence in the present study that rumen chronic acidotic conditions modified the microbial capacity to synthesize thiamin. It can be proposed that under these conditions $\mathrm{CCN}$ does not have a ruminal origin. However, some further studies will be undertaken to explore the incidence of an acute lactic acidosis state on rumen thiamin production.

In vivo duodenal thiamin flow was found to be positively correlated to thiamin intake (Breves et al. 1981; Miller et al. 1986). Similarly in our experiment, total thiamin output increased when external thiamin was added. However net thiamin production decreased when external thiamin was added. This supports in vivo observations where $30-50 \%$ of dietary thiamin may be degraded before reaching the duodenum (Steinberg \& Kaufmann, 1977) and where ruminal destruction of thiamin tended to increase when the thiamin intake increased (Miller et al. 1986).

In the present experiment, the level of addition of free thiamin, which corresponded to approximately the amount of microbial thiamin that would be produced in the absence of added thiamin, induced only a very small increase in the proportion of free thiamin and a decrease in the proportion of TPP. Nevertheless, the total output of TPP increased in this 
case (356 v. $261 \mathrm{nmol} / \mathrm{d})$. This indicated that added thiamin was phosphorylated and widely utilized by rumen bacteria. We have no evidence for the amount of added thiamin which was degraded but it may be assumed that the degradation was very low because the observed thiaminase activity was low. It is, thus, probable that the external input of thiamin inhibited microbial thiamin synthesis per se. In fact it has previously been shown by Newell \& Tucker (1966) that addition of TPP can have a strong inhibitory effect on thiazole synthesis and the pyrimidine cycle in non-ruminal bacteria.

No effect of thiamin addition on SCFA production or microbial protein synthesis was obtained. Some authors found that thiamin addition in vitro enhanced SCFA production and microbial protein synthesis (Höller et al. 1978; Candau \& Kone, 1980), but these effects have been obtained with very high thiamin supplements, whereas we used a thiamin level near to the average ruminant dietary intake.

Amongst all of the factors investigated, only a high level of $\mathrm{S}$ decreased net thiamin production. In previous studies, using short duration in vitro models (Bick et al. 1978; Olkowski et al. 1993) an increase in degradation was associated with S excess. It must be emphasized that in such models net thiamin synthesis did not occur. Thus, they have been utilized only to study vitamin catabolism. Despite the fact that microbial metabolism of thiamin was sensitive to a high-S diet, the range of depression observed was not likely to induce a severe deficiency in thiamin of microbial origin as net thiamin production remained within the range of normal in vivo values. This is confirmed by the fact that in vivo, in lambs receiving a high-S semi-purified diet deprived of thiamin, it was not possible to demonstrate a modification of thiamin status after 16 weeks (Alves de Oliveira et al. 1996).

The authors gratefully acknowledge Mrs M. Carcelen and Mrs C. Huc for their technical assistance, Mr P. Mougel for his computer assistance, Fiona O'Sullivan for the advice in English and Dr Roger Merry for helpful advice and revision of the final version of the manuscript. Financial support was provided by a grant-in-aid (no. 93521) from the DGER Office of Ministry of Agriculture.

\section{REFERENCES}

Alves de Oliveira, L., Jean-Blain, C., Dal Corso, V., Bénard, V., Durix, A. \& Komisarczuk-Bony, S. (1996). Effect of a high sulphur diet on the rumen microbial activity and rumen thiamin status in sheep receiving a semi-synthetic, thiamin-free diet. Reproduction, Nutrition, Développement 36, 31-42.

Bechdel, S. I., Honeywell, H. E., Dutcher, R. A. \& Knutson, M. H. (1928). Synthesis of vitamin B in the rumen of the cow. Journal of Biological Chemistry 80, 231-238.

Bick, S., Breves, G. \& Höller, H. (1978). Netto synthese von mikrobiellem Protein und Thiamin im Panseninhalt eiweissfrei ernährter Schafe bei unterschiedlichen Substrat-und Schwefelkonzentrationen in vitro (In-vitro net synthesis of microbial protein and thiamin in rumen contents of sheep adapted to a protein-free diet: effects of varying levels of substrate and sulphur). Zeitschrift für Tierphysiologie, Tierernährung und Futtermittelkunde 41, 8-17.

Bousquet, B., Fiet, J., Julien, R., Bon, R. \& Dreux, C. (1971). Application aux milieux biologiques de la réaction de l'urée avec la diacétylmonoxime sensibilisée par la thiosemicarbazide (Application of urea reaction with diacetylmonoxim sensitized by thiosemicarbazide to biological media). Annales de Biologie Clinique 29, 415-422.

Boyd, J. W. (1985). Studies on thiaminase I activity in ruminant faeces and rumen bacteria. Journal of Agricultural Science, Cambridge 104, 637-642.

Boyd, J. W. \& Walton, J. R. (1977). Cerebrocortical necrosis in ruminants: an attempt to identify the source of thiaminase in affected animals. Journal of Comparative Pathology 87, 581-589.

Bray, A. C. (1964). The recycling and excretion of sulphur in sheep. Proceedings of the Australian Society of Animal Production 5, 336-344.

Brent, B. E. \& Bartley, E. E. (1984). Thiamin and niacin in the rumen. Journal of Animal Science 59, 813-822. 
Breves, G., Brandt, M., Hoeller, H. \& Rohr, K. (1981). Flow of thiamin to the duodenum in dairy cows fed different rations. Journal of Animal Science 96, 587-591.

Breves, G., Höller, H., Harmeyer, J. \& Martens, H. (1980). Thiamin balance in the gastrointestinal tract of sheep. Journal of Animal Science 51, 1177-1181.

Candau, M. \& Kone, L. (1980). Influence de la thiamine sur la protéosynthèse bactérienne chez le mouton (In vitro effect of thiamin on rumen microbial metabolism). Reproduction, Nutrition, Développement 20, 16951699.

Cline, J. D. (1969). Spectrophotometric determination of hydrogen sulphide in natural waters. Limnology and Oceanography 14, 454-458.

Counotte, G. H. M. \& Prins, R. A. (1981). Regulation of lactate metabolism in the rumen. Veterinary Research Communications 5, 101-115.

Cummings, B. A., Gould, D. H., Caldwell, D. R. \& Hamar, D. W. (1995a). Identity and interactions of rumen microbes associated with dietary sulphate-induced polioencephalomalacia in cattle. American Journal of Veterinary Research 56, 1384-1389.

Cummings, B. A., Gould, D. H., Caldwell, D. R. \& Hamar, D. W. (1995b). Ruminal microbial alterations associated with sulphide generation in steers with dietary sulphate-induced polioencephalomalacia. American Journal of Veterinary Research 56, 1390-1395.

Czerkawski, J. W. \& Breckenridge, G. (1977). Design and development of a long term rumen simulation technique (RUSITEC). British Journal of Nutrition 38, 371-384.

Demeyer, D. I. \& Van Nevel, C. J. (1979). Effect of defaunation on the metabolism of rumen micro-organisms. British Journal of Nutrition 42, 515-524.

Edwin, E. E. \& Jackman, R. (1973). Ruminal thiaminase and tissue thiamine in cerebrocortical necrosis. Veterinary Record 92, 640-641.

Erflé, J. D., Boila, R. J., Teather, R. M., Mahadevan, S. \& Sauer, F. D. (1982). Effect of pH on fermentation characteristics and protein degradation by rumen microorganisms in vitro. Journal of Dairy Science 65, $1457-$ 1464.

Gooneratne, S. R., Olkowski, A. A. \& Christensen, D. A. (1989). Sulphur-induced polioencephalomalacia in sheep: some biochemical changes. Canadian Journal of Veterinary Research 53, 462-467.

Grigat, G. A. \& Mathison, G. W. (1982). Thiamin supplementation of all-concentrate diet for feedlot steers. Canadian Journal of Animal Science 62, 807-819.

Gutmann, I. \& Wahlefeld, A. W. (1974). L(+) lactate: determination with lactate dehydrogenase and NAD. In Methods of Enzymatic Analysis, 2nd ed., vol. 3, pp. 1464-1468 [H. U. Bergmeyer, editor]. New York: Academic Press.

Hamlen, H., Clark, E. \& Jansen, E. (1993). Polioencephalomalacia in cattle consuming water with elevated sodium sulphate levels: a herd investigation. Canadian Journal of Animal Science 34, 153-158.

Harmeyer, J. \& Kollenkirchen, U. (1989). Thiamin and niacin in ruminant nutrition. Nutrition Research Reviews 2, 201-225.

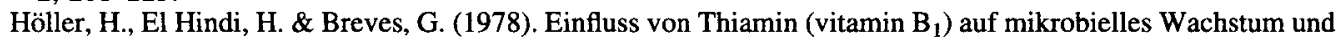
Bildung von flïchtlichen Fettsäuren in vitro im Pansensaft proteinfrei ernährter Schafe (Effect of thiamin (vitamin $B_{1}$ ) on microbial net growth and production of volatile fatty acids in vitro in rumen liquid of sheep fed a protein-free diet. Deutsche Tierärztliche Wochenschrift 85, 200-202.

Hoover, W. H., Kincaid, C. R., Varga, W. V., Thayne, W. V. \& Junkins, L. L. (1984). Effects of solids and liquid flows on fermentation in continuous cultures. IV. $\mathrm{pH}$ and dilution rate. Journal of Animal Science 58, 692699.

Hubbert, F., Cheng, E. \& Burroughs, W. (1958). Mineral requirements of rumen microorganisms for cellulose digestion in vitro. Journal of Animal Science 17, 559-568.

Johnson, W. H., Meiske, J. C. \& Goodrich, R. D. (1968). Influence of high levels of two forms of sulphate on lambs. Journal of Animal Science 27, 1166.

Jouany, J. P. (1982). Volatile fatty acids and alcohol determination in digestive contents, silage juices, bacterial cultures and anaerobic fermenter contents. Sciences des Aliments 2, 131-144.

Kandylis, K. (1984). The role of sulphur in ruminant nutrition. A review. Livestock Production Science 11, 611624.

Kennedy, L. G., Mitchell, G. E. \& Little, C. O. (1971). Influence of sulphur on in vitro starch digestion by rumen microorganisms. Journal of Animal Science 32, 359-363.

Kumaresan, A. (1976). Interactions entre le zinc et les microorganisms du rumen chez le mouton recevant de l'urée comme source unique d'azote (Interaction between zinc and rumen microorganisms in sheep fed urea as sole nitrogen source). PhD Thesis, University of Toulouse.

Linklater, K. A., Dyson, D. A. \& Morgan, K. T. (1977). Faecal thiaminase in clinically normal sheep associated with outbreaks of polioencephalomalacia. Research in Veterinary Science 22, 308

Loew, F. M. (1975). A thiamin responsive polioencephalomalacia in tropical and nontropical livestock production systems. World Review of Nutrition and Dietetics 20, 168-183. 
Low, J. C., Scott, P. R., Howie, F., Lewis, M., FitzSimons, J. \& Spence, J. A. (1996). Sulphur-induced polioencephalomalacia in lambs. Veterinary Record 138, 327-329.

Lusby, K. S. \& Brent, B. E. (1972). An experimental model for polioencephalomalacia. Journal of Animal Science 35, 270.

McAllister, M. M., Gould, D. H. \& Hamar, D. W. (1992). Sulphide-induced polioencephalomalacia in lambs. Journal of Comparative Pathology 106, 267-278.

Manka, D. P. (1964). Complete gas chromatographic analysis of fixed gases with one detector using argon as gas carrier. Analytical Chemistry 36, 480-482.

Miller, B. L., Meiske, J. C. \& Goodrich, R. D. (1986). Effects of grain source and concentrate level on B-vitamin production and absorption in steers. Journal of Animal Science 62, 473-483.

Miller, T. L. (1978). The pathway of formation of acetate and succinate from pyruvate by Bacteroides succinogenes. Archives of Microbiology 117, 145-152.

Morgan, K. T. \& Lawson, G. H. K. (1974). Thiaminase type I producing bacilli and ovine polioencephalomalacia. Veterinary Record 95, 361-363.

Murphy, M. (1993). The pH fluctuation in the rumen of lactating cows. Acta Veterinaria Scandinavica 89, 164 165.

Nakamura, I., Oginoto, K., Imai, S. \& Nakamura, M. (1989). Production of lactic acid isomers and change of microbial features in the rumen of feedlot cattle. Journal of Animal Physiology and Animal Nutrition 61, 139 144.

Newell, P. C. \& Tucker, R. G. (1966). The control mechanism of thiamine biosynthesis. Biochemical Journal 100, 517-524.

Olkowski, A. A., Laarveld, B., Patience, J. F., Francis, S. I. \& Christensen, D. A. (1993). The effect of sulphate on thiamine-destroying activity in rumen content cultures in vitro. International Journal for Vitamin and Nutrition Research 63, 38-44.

Qi, K., Lu, C. D. \& Owens, F. N. (1993). Sulfate supplementation of growing goats: effects on performance, acid-base balance, and nutrient digestibilities. Journal of Animal Science 71, 1579-1587.

Raisbeck, M. F. (1982). Is polioencephalomalacia associated with high sulphate diets? Journal of the American Veterinary Medical Association 180, 1303-1305.

Rousseaux, C. G., Olkowski, A. A., Chauvet, A., Gooneratne, S. R. \& Christensen, D. A. (1991). Ovine polioencephalomalacia associated with dietary sulphur intake. Journal of Veterinary Medicine 38A, 229-239.

Rumsey, T. S. (1978). Effects of dietary sulphur addition and synovex-S ear implants on feedlot steers fed an allconcentrate finishing diet. Journal of Animal Science 46, 463-477.

Russell, J. B. \& Dombrowski, D. B. (1980). Effect of $\mathrm{pH}$ on the efficiency of growth by pure culture. Applied and Environmental Microbiology 39, 604.

Shi, Y. \& Weiner, P. J. (1992). Response surface analysis of effects of $\mathrm{pH}$ and dilution rate on Ruminococcus flavefaciens FD-1 in cellulose-fed continuous culture. Applied and Environmental Microbiology 58, 25832591.

Shreeve, J. E. \& Edwin, E. E. (1974). Thiaminase-producing strains of $C l$. sporogenes associated with outbreaks of cerebrocortical necrosis. Veterinary Record 13, 330.

Sorbö, B. (1987). Sulphate: turbidimetric and nephelometric methods. Methods in Enzymology 143, 3-6.

Statistical Analysis Systems (1985). SAS User's Guide, Statistics. Cary, NC: SAS Institute Inc.

Steinberg, W. \& Kaufmann, W. (1977). Untersuchungen zur bakteriellen Thiaminsynthese in den Vormägen von Milchkühen (Investigations on the bacterial thiamine synthesis in the rumen of dairy cows). Zeitschrift für Tierphysiologie, Tierernährung und Futtermittelkunde 39, 289-301.

Thomas, K. W. (1986). The effect of thiaminase-induced subclinical thiamine deficiency on growth of weaner sheep. Veterinary Research Communications 10, 125-141.

Tournut, J., Labie, Ch. \& Espinasse, J. (1967). Identification en France de la 'Nécrose du Cortex Cérébral' (NCC) chez plusieurs espèces de ruminants (Cerebrocortical necrosis identification in several ruminant species in France). Revue de Médecine Vétérinaire 118, 883-896.

Weatherbum, M. W. (1967). Phenol hypochlorite reaction for determination of ammonia. Analytical Chemistry 89, 971-974.

Wolin, J. M. \& Miller, T. L. (1983). Interactions of microbial populations in cellulose fermentation. Federation Proceedings 42, 109-113. 